\title{
GEORGIUS HUSZTHIUS, A TRAVELLER FROM CROATIA, AND HIS ACCOUNT OF THE OTTOMAN NAVAL CAMPAIGN IN INDIA (1538-1539)
}

\author{
ANĐELKO VLAŠIĆ \\ TÜBİTAK Research Fellow, History Department, Koç University \\ Rumelifeneri Yolu, 34450 Sariyer/Istanbul, Turkey \\ e-mail: andelko.vlasic@gmail.com
}

This paper analyses the description of the Ottoman naval campaign in India (1538-1539) in the travelogue of the Croatian traveller Georgius Huszthius, a trumpeter in the fleet of Hâdım Süleyman Pasha during the Indian campaign; thus he is an excellent witness to these events. The aim is to compare Huszthius's account with other primary sources for the mentioned events and secondary sources published up to now. Huszthius's travelogue named Descriptio peregrinationis Georgii Huszthii and published in 1881 is historically significant, because it gives us new information about the mentioned Ottoman campaign and also corroborates the testimonies of the Portuguese chroniclers and of an anonymous Venetian author whose journal Viaggio di un comito Veneziano da Alessandria all' assedio di Diu was published in Venice in 1540. Huszthius's and the unknown Venetian's works represent the only two first-hand accounts of the Indian campaign from the side of the crew of the Ottoman fleet. Their works confirm Portuguese primary sources and give us a more balanced view on Hâdım Süleyman Pasha's naval campaign. Huszthius's travelogue's section concerning the Ottoman naval campaign in India and the siege of Diu still has not been fully examined by Turkish historians and this paper is an attempt to ameliorate that situation.

Key words: Georgius Huszthius, India, Ottoman naval campaign, siege of Diu, Hâdım Süleyman Pasha.

\section{Primary Sources for the Ottoman Campaign in India}

Researchers use as primary sources only Portuguese accounts of the Indian campaign and the report of an unknown Venetian boatswain who was, among other Venetian sailors, employed by Hâdım Süleyman Pasha during the Indian campaign (Kerr 1812, p. 257). The main Portuguese sources for the history of the siege of Diu of 1538 are two books. The first is named Da Ásia by the authors Diogo do Couto and João de Barros, of whom the latter one is the author of the relevant part, named Dos feitos 
que os Portuguezes fizeram no descubrimento, e conquista dos mares, e terras do Oriente. Decada quarta. Parte segunda (The deeds that the Portuguese did in the discovery and conquest of the seas and lands of the Orient. Volume four. Part two), printed by the Régia Officina Typografica of Lisbon between 1777 and 1788. The other book was written by Lopes de Sousa Coutinho and is called Historia do cerco de Dio (The history of the siege of Dio), printed in Lisbon in 1890. Valuable treatises on the afore-mentioned event are papers published by Luciano Ribeiro: O primeiro cerco de Dio (The first siege of Dio), published in Studia No. 1, pp. 201-295 in 1958, Preâmbulos do primeiro cerco de Diu (Preambles to the first siege of Diu), Studia No. 10, pp. 151-193, 1962, Em torno do primeiro cerco de Diu (About the first siege of Diu), Studia Nos 13-14, pp. 41-104, 1964, and a book named Mais documentos relativos ao primeiro cerco de Dio (More documents relating to the first siege of Dio), published in Lisbon in 1966.

As for the Ottoman sources, one must point out that Ottoman narratives of the siege are rare. One source is a book by Kâtib Çelebi called Tuhfetü'l-Kibâr fi Esfâri'l-Bihâr, printed by İbrahim Müteferrika in Istanbul in 1729. Hâdım Süleyman Pasha's own account is missing from his collection of letters (Kurtoğlu 1940). The Turkish researcher Ertuğrul Önalp (2008, pp. 236-237) used the books of Portuguese authors who in turn used the anonymous Venetian's account when describing the Ottoman fleet's activities in the Indian Ocean.

As for the anonymous Venetian author, there are two printed versions of his account, both in Italian. The first is called Viaggio di un comito Veneziano da Alessandria all' assedio di Diu (Voyage of a Venetian boatswain, from Alexandria to Diu) and it was printed in Venice in 1540 (Kerr 1812, p. 257). The second version is named Viaggio scrito per un comito venetiano che fu condoto prigione dalla citta de Alessandria fino al Diu nella India, col suo ritorno, poi al Cairo del 1538 (Voyage written by a Venetian boatswain who was imprisoned in the city of Alexandria, and which finished in Diu, in India, until his return through Cairo, in 1538) (Anonymous Author 1550, Vol. II, pp. 1476-1509). These descriptions differ in several respects, not only in their titles, but also in both substance and diction (Kerr 1812, p. 257).

\section{Georgius Huszthius's Life and Travels}

Georgius Huszthius (his Latin name) or Juraj Hus Rasinjanin (his Croatian name) (written also as Gjuro/Đuro Hus/Huz/Hwz/Husz/Husti/Huszti) was born in ca. 1510 in Rasinja (today Croatia, then part of the Hungarian Kingdom) and died after 1566 in Pozsony (today Bratislava, in Slovakia). Huszthius was the first known renaissance traveller and travelogue writer from Croatia. He was a native of the village of Rasinja and thus called "de Rascinia", "de Rasinya", or "Rasciniensis" (Istvánffy 1622, Vol. XI, p. 115; Horányi 1776, Vol. I, p. 189). Huszthius was educated in the Latinist curriculum at the University of Pécs in Hungary. As a young man, in 1532 he was abducted from his village by Ottoman soldiers on their retreat from an unsuccessful military campaign to Vienna. He was taken to Istanbul as a slave of the Ottoman def- 
terdar İskender Çelebi, and he spent the next ten years (1532-1542) in the Muslim world of the Middle East. As an Ottoman slave, he took part in Sultan Süleymanthe Magnificent's military campaign against Persia (1534-1536). When defterdar İskender Çelebi fell into disgrace and was hanged in Baghdad, his property was transferred to İbrahim Pasha, and later to the Sultan. Huszthius became an apprentice trumpeter in the service of the musical master Pervane Usta in Galata, Istanbul. After four years he was liberated by the Sultan, with limited mobility right throughout the Ottoman Empire. Soon afterwards he enlisted as a military trumpeter: he was hired for a better salary, and from 1536 to 1538 he practised in Egypt with the army units. Subsequently he took part in the naval campaign in India as a trumpeter. Afterwards, back in Cairo, Huszthius decided to leave the army and head back home, this time as a pilgrim, and he went to Jerusalem, Damascus, Anatolia, the island of Khios, Sicily, Naples, Genoa, Rome, Ancona, Rijeka, Zagreb, and finally Pozsony (now Bratislava in Slovakia), capital of the Hungarian Kingdom under Habsburg rule, where he died around 1566 (Krasić 1993, Vol. 3, p. 68; Stepanić 2011, p. 1). His manuscript represents one of the most valuable travelogues of the 16th century (Humski 2002, Vol. 5, p. 17; Laszowski 1925, p. 112).

\section{Description of Georgius Huszthius's Manuscript}

Several years after Huszthius returned home, he decided to write a report which would be a recount of his travels. One should bear in mind that Huszthius had a classical humanist education, hence he wrote in Latin. His travelogue has been preserved in two manuscript versions: the first, entitled Georgii Huz peregrinatio Hierosolimitana (The pilgrimage of Georgius Huz to Jerusalem), written in Latin and dated 10th November 1548, in Pozsony (today Bratislava), is preserved in the Austrian National Library in Vienna, Austria (Österreichische Nationalbibliothek, under the signature 9528). It is a copy of the text the author claims to have sent to Emperor Ferdinand I of Habsburg in the same year. Much later, in 1566, Huszthius wrote a new, expanded and more elaborate version of his voyages named Descriptio peregrinationis Georgii Huszthii (Description of the travel of Georgius Huszthius), also in Latin, dated 27th October 1566, and dedicated to Hieronymus Beck, Emperor Ferdinand's counsellor. The manuscript of the latter version was transcribed in Kroatisch-Jahrndorf (Hungarian: Horvátjárfalu, Croatian: Hrvatski Jandrof), today in Slovakia, and is preserved in the Vatican Library in Rome (Codex Bibliothecae Vaticanae Romae) under the registration number 931 (fol. 30, pag. 60) (Stepanić 2011, p. 1; Krasić 1993, Vol. 3, p. 68).

Croatian academician Petar Matković edited and published Husztius's manuscript with commentaries in 1881 (Huszthius 1881). This edition is based on the later manuscript but different parts of text from the older manuscript are added to illustrate differences between the two versions. The edition comprises 38 pages (Matković 1881; Stepanić 2011, p. 1). Huszthius's work was translated into Hungarian by the Hungarian historian Lajos Tardy in 1977. This book includes a short introduction, the text of the 
manuscript and notes (Tardy 1977, pp. 208-269) ${ }^{1}$. It is important to mention that Huszthius's manuscript is not a journal but a retrospective interpretation of past events. Huszthius extensively narrates his travels throughout the Middle East and the wars in which he participated. He also relatively precisely described the Indian campaign on seven pages of his manuscript. One may argue that his work is one of the most literate and attractive works (from the viewpoint of a layman lecturer) amongst the so-called prisoner travelogues of European Christians in the Ottoman Empire, including Johann Schiltberger's Reisebuch (Homann 1995, Vol. VII, pp. 1465-1466) and Bartholomeus Georgievits's Libellus vere Christiana lectione dignus diversas res Turcharum brevi tradens (A book worthy of reading by a Christian providing information on the Turks) (Krasić 1993, Vol. 3, p. 68; Stepanić 2011, pp. 3-4). However, Huszthius's work was not at all popular unlike the afore-mentioned works of Schiltberger and Georgievits which were extensively re-printed. Georgievits's travelogue, for example, was printed 64 times between 1544 and 1598 alone! (Miličić 2013, p. 165). Nevertheless, Huszthius's travelogue is an extremely valuable work. The manuscript is replete with Biblical and Classical digressions which clearly show his humanist erudition, because he cites, among others, Homer, Aristotle, Pliny the Younger, Seneca, Plautus, Ovid, Virgil, Juvenal, etc. (Krasić 1993, p. 68). His travels all the way to India and back were worthy enough of being mentioned in the Austrian Orientalist Joseph von Hammer-Purgstall's (1774-1856) principal work, Geschichte des osmanischen Reiches (Hammer 1828, Vol. III, pp. 209-211).

What does Huszthius's work offer that one cannot already find in the unknown Venetian sailor's journal? First of all, the topographic descriptions of the two authors are concurrent. The differences stem from their personalities and their education: the anonymous Venetian is a sailor, a boatswain, and that is why his account is full of measurements, names of places, directions according to the sides of the world, directions of the winds, information about the inhabitability of the regions they were coming across, etc. One can say it is a true seaman's journal. On the other hand, Huszthius's testimony is a collection of memories written long after the events he describes. The oldest version of the account, from the Viennese manuscript, was completed in 1548 , sixteen years after the adventure started and six years after it ended. The report does not suggest that its author ever took written notes of the events or places he visited. This is supported by the fact that he mentions only the most important harbours. However, Huszthius's travelogue is focused on the motifs and the subject of the naval campaign (Matković 1881, p. 142) and that is why his account gives us a more clear-cut picture of the Ottoman campaign than the journal of the Venetian author.

There are places in the manuscript where Huszthius even renounces the role of a chronicler of Ottoman history (Matković 1881, p. 142). Nevertheless, as a way of confirming the historicity of his testimony, Huszthius describes how a group of Venetian sailors were also present on the Ottoman ships, and that they had seen all the events

${ }^{1}$ Short introduction: p. 208, text: pp. 209-261, notes: pp. 261-269. Tardy's introductory notes and bibliography are also important: pp. $23-26$, and notes on pp. 26-38 and 45-46. 
just as he did. More importantly, one of the Venetian rowers was writing a journal, and that person must have been the unknown Venetian author already mentioned before (Huszthius 1881, p. 14; Matković 1881, p. 130).

\section{Motivation for the Ottoman Naval Campaign in India}

After their conquest of Egypt in 1517, the Ottomans strived to be the real protectors of the Holy Cities and the masters of the old trade routes. The main rival in the latter quest was Portugal because it reached India and mastered the Indian Ocean sea routes along which the eastern spices flowed to Europe (Mathew 1988, p. 214). The call for help directed towards the Ottoman Empire from the Muslim states of the Indian Peninsula was also essential for the Ottoman activity in the region. The Portuguese were harming Ottoman trade prospects as well as the well-being of the mentioned Muslim states in India (Mughul 1974, pp. 135-137).

During the reign of Sultan Süleyman the Magnificent four separate naval campaigns were dispatched to the Indian Ocean between 1538 and 1554. The first Indian naval campaign (1538-1539) was to aid Sultan Quṭb al-Dīn Bahādur Shah of the Gujarat Sultanate (1526-1535; 1536-1537), who appealed to Süleyman the Magnificent for joint action against the Portuguese forces in India after they took the city of Diu. The Ottoman Sultan used this opportunity to check Portuguese domination in the Indian Ocean and appointed Hâdım Süleyman Pasha as the supreme commander of the Indian Ocean fleet that was to assist the Gujaratis. The initial aim might also have been to spread the Ottoman rule into India. Hâdım Süleyman Pasha (cca. 1467-1547) was the governor of Ottoman Egypt $(1525-1535 ; 1537-1538)$ and Grand Vizier of the Ottoman Empire (1541-1544) (Aslan 1999, Vol. 2, p. 567). Bahādur Shah had been killed in 1537 during a clash with the Portuguese navy and his successor, Mahmud Shah III, who succeeded the deceased sultan Bahadur Shah, had allied himself with Portugal. These facts did not change Hâdım Süleyman Pasha's actions as he continued to execute the Sultan's plan (Mughul 1974, pp. 135-137).

\section{Preparation of the Ottoman Fleet}

The Ottoman and Portuguese sources suggest that the Ottoman fleet was prepared in the vicinity of the Egyptian city of Suez and it probably consisted of 76 ships of different type and size: 6 great galleys (Italian: galea bastarda; Turkish baştarda), 17 galleys of normal size (Turkish kadirga), 27 small galleys (Turkish and Portuguese fusta) and the others were smaller galleys, ships and boats. Other authors give even more detailed description of the preparation of the Ottoman Red Sea fleet and its probable size (Önalp 2008, pp. 198-201; Mughul 1974, pp. 134-137). What this paper will analyse is the fleet's activity in western India in comparison with the Venetian's and Huszthius's testimony, and not the totality of details of the mentioned campaign. As for the anonymous Venetian sailor, he states that the fleet consisted of 74 ships, and 
Huszthius mentions only 54 bigger ships and four smaller galleys (Matković 1881, p. 137). We should agree with the Venetian author because Kâtib Çelebi also mentions 70 ships (Çelebi 2007, p. 198). In any case, it was the largest Ottoman fleet ever dispatched to the Indian Ocean, and with a total crew approaching ten thousand individuals, it dwarfed contemporary Portuguese fleets (Casale 2010, p. 59).

The fleet did not consist only of Turkish sailors and soldiers. Using the Ottoman Empire's declaration of war against Venice in 1537 as a pretext, Hâdım Süleyman Pasha impounded all of the Venetian merchant vessels in Egypt and employed their crew to serve in his fleet. Thus the Ottoman force was augmented by hundreds of Venetian gunners, officers, rowers, carpenters and skilled craftsmen who were used as assistants in fitting out the Ottoman fleet (Çelebi 2007, p. 198; Casale 2010, p. 59; Kerr 1812, p. 257). Their voyage was performed by compulsion, having been forced to accompany Hâdım Süleyman Pasha on his campaign. There were 173 Venetian sailors on the Ottoman ships, says the Venetian author, and they were chained to the rowing benches of the Ottoman ships (Anonymous Author 1550, Vol. II, p. 1477). Huszthius also mentions the Venetian slave-rowers on the galleys and says that they were men from Dalmatia, a region on the eastern shore of the Adriatic Sea. Many of these rowers were probably speaking the same language as Huszthius did, i.e. Croatian (Matković 1881, p. 129).

Hâdım Süleyman Pasha chose Yusuf Hamid, Bey of Alexandria, as his admiral of the Indian fleet (Cezar 1958, p. 1004). Huszthius relates in his manuscript how a man of Arab descent (presumably Yusuf Hamid) came to Istanbul in 1536 to recruit volunteers for the military campaign to India. Huszthius took this chance and enlisted for the Ottoman fleet. From 1536 to 1538 he practised in Egypt with the army units as a trumpeter, and later was commissioned as a trumpeter on Yusuf Hamid's ship (Huszthius 1881, p. 17; Matković 1881, p. 137). So he was personally involved in the campaign on one of the leading ships of the Ottoman fleet; thus he is an excellent witness to these events. The anonymous Venetian author also mentions the Pasha's principal marine officer, but does not state his name; instead, he calls him "the Moorish captain" and mentions him several times as one of the most recognised officers of Hâdım Süleyman Pasha's crew (Anonymous Author 1550, p. 1496; Kerr 1812, p. 272).

Huszthius states that he lived in Egypt for two years until the ships on the Red Sea were prepared for the campaign and that his Arab captain was supervising the repair of the warships in Suez harbour. Huszthius travelled many times with him during these two years from Alexandria to Suez and along the coast of the Red Sea where the ships were being repaired and prepared (Huszthius 1881, p. 15; Matković 1881, p. 129).

As an interesting fact, both authors mention the siege cannons that were transported to the Ottoman ships. There were nine cannons of extraordinary calibre that shot bullets $200 \mathrm{~kg}$ heavy and reminded people of the stories of Sultan Mehmed II's cannons and the siege of Istanbul (Hammer 1828, pp. 210-211). The magnificence of those cannons was so great that they caught the eyes of the crew and of our narrators. 


\section{The Conquest of Aden and the Voyage from Aden to Diu}

After its departure, the Ottoman fleet passed through the Red Sea and entered the Gulf of Aden. The Venetian author writes in detail about that part of the voyage. On the other hand, Huszthius's account is more concise. We will not describe their testimonies about that part of the campaign and will instead focus on the most divergently described event, the conquest of the city of Aden. It is one of the events of the Ottoman naval campaign that was thoroughly analysed by Turkish historians. The Ottoman fleet stopped on their way to seize that city, and Ertuğrul Önalp cites plentiful sources for this event (Önalp 2008, pp. 206-210), but does not mention Huszthius's testimony.

The ruler of Aden, Amir ben Daud, was tricked onto the Pasha's ship and hanged on the main mast. Then, under the pretext of loading the provisions needed for the voyage, the Ottoman fleet entered the internal harbour of Aden, without resistance from the inhabitants of the city (Matković 1881, p. 121). The Venetian author recounts the same story about Hâdım Süleyman Pasha's deceitful action (Anonymous Author 1550, pp. 1479-1480; Kerr 1812, pp. 260-262), but Huszthius's testimony is more precise. Although he does not state any facts that are different from what we today know, he describes the layout of the city and the activity of the Janissaries of the Ottoman fleet in more detail (Huszthius 1881, p. 16; Matković 1881, pp. 132$133,142)$.

The Venetian author states that the fleet departed from Aden on the 19th August with 74 ships in all, reckoning galleys, foists (fustas) and lesser vessels (Anonymous Author 1550, p. 1480; Kerr 1812, p. 262). Huszthius corroborates his testimony and adds that the fleet was equipped with plentiful food rations before leaving Aden (Huszthius 1881, p. 18).

According to Huszthius, with strong wind it took them 19 days to come from Aden to Diu, but he does not mention the dates of departure from Aden and arrival to Diu (Huszthius 1881, p. 16; Matković 1881, pp. 135-136). As the Venetian author mentions that the fleet cast anchor within three miles of Diu on the 4th September (Anonymous Author 1550, p. 1481; Kerr 1812, p. 263), this would give them 16 days of travel from Aden to Diu according to the Venetian source. So, the duration of that part of the voyage remains unclear even after the comparison of those two sources.

\section{Events during the Siege of Diu}

The Ottoman fleet arrived at the coast of the Gujarat Peninsula, on the western shore of India, on 4th September, as the Venetian author states. Diu was a strongly fortified city situated on the south coast of the Gujarat Peninsula. Khoja Zaffar, commander of the forces of the Sultan of Diu, made contact with Hâdım Süleyman Pasha and the plan was to jointly capture the fort of Diu. Khoja Zaffar was received on Hâdım Süleyman Pasha's ship with much honour and he informed the Pasha that there were 500 Portuguese soldiers and 300 others in the castle of Diu, which the Indian Muslim Gujarati forces had besieged for 26 days, and had no doubt of being able to capture it 
with their Indian troops if the Pasha would furnish them with artillery and ammunition. The Pasha presented him with gifts, states the Venetian author. But while Khoja Zaffar remained on board, the Ottoman troops plundered the city of Diu (separate from the fort of Diu). They likewise advanced towards the castle of Diu and skirmished with the Portuguese garrison. When the Gujaratis were acquainted with the outrages committed by the Ottoman forces on the shore, they retired from the fort of Diu with 6000 men, going immediately to the king Mahmud Shah III (Anonymous Author 1550, pp. 1481-1482; Kerr 1812, pp. 263-264).

That event left the Ottoman forces in a bad position during the rest of the siege. The reasons for the later hasty retreat of the Ottoman fleet should be seen in the animosity that the local Indian Muslim kingdoms had against them. Both Portuguese sources and the Venetian author's account testify to these events. The reason for that animosity was either Hâdım Süleyman Pasha's actions (the plunder of the city of Diu) or the Indian Muslim kingdoms' fear that the Ottomans would acquire hegemony in Diu and, subsequently, in India (Önalp 2008, pp. 216-217).

The anonymous Venetian sailor describes in his account how on the 6th September the Ottoman galleys sent their boats filled with Janissaries to assist the native Indian troops who were encamped around the castle, these being now reduced to not more than 2000 men, as all the rest had departed along with Khoja Zaffar (Anonymous Author 1550, pp. 1481-1482; Kerr 1812, pp. 263-264).

The unknown Venetian author tends to describe events that one can hardly believe the Venetian really had seen, because his stories are full of disputable things: a 300-year-old man, people riding on oxen, etc. On the other hand, Huszthius only relates what he actually saw during the campaign. But both authors are mostly very reliable because they mention cannons of extraordinary magnitude and the capturing of the small fortress and its eighty Portuguese defenders. The anonymous narrator is more precise than Huszthius when he describes the position of the cannons around the fort, how heavy the balls for the cannons were, how the defenders fixed the damage from the Ottoman cannons, and how they were from time to time charging from the fort (Matković 1881, p. 143). Huszthius also describes the event of unloading the giant cannons on the shore, the non-stop firing at the castle of Diu and the damage it caused, and is very specific, too, when he states that the Ottoman gunners continued to fire cannons for forty days, and that it was the Arab captain (presumably Yusuf Hamid) attacking and firing with the guns from his ships from the seaside towards the fortress. Nevertheless, the two authors are concurrent when they describe how the Portuguese were fighting courageously and how many Ottoman soldiers lost their lives, to no avail (Huszthius 1881, p. 17. Matković 1881, p. 136).

Joseph von Hammer-Purgstall in his book Geschichte des osmanischen Reiches mentions Huszthius's travelogue and compares it with Western and Eastern sources for the Indian campaign, but Hammer-Purgstall did not use all pertinent information from Huszthius's account. For example, Hammer-Purgstall's sources state that the Ottomans captured two smaller fortresses of the fort complex of Diu (Kuke and Kat) by storming them, but neither Huszthius nor the Venetian author state this fact (Matković 1881, p. 146). However, both authors mention one other captured object that 
could probably be identified as one of the smaller fortresses Hammer-Purgstall mentions. On the 1st October, a messenger came from the tower called Gogola, which was one of the towers of the entire complex, and offered to capitulate, being no longer able to hold out. The Ottoman artillery pierced the tower through and through, so that the stones flew about and had slain twenty men out of a hundred in the garrison. The captain of the Portuguese garrison, whose name was probably Juan Francisco Pacheco, surrendered with eighty of his soldiers (Anonymous Author 1550, p. 1486; Kerr 1812, pp. 268-269). This is the Venetian author's testimony and, so far, it was the only source (Önalp 2008, pp. 219-220), but Huszthius also mentions that Hâdım Süleyman Pasha ordered his men to attack the back tower (which he does not name) with eighty Portuguese soldiers stationed in it (Huszthius 1881, p. 17; Matković 1881, p. 136). On the 3rd October, claims the unknown Venetian author, the Pasha ordered all the Portuguese soldiers who had surrendered to be distributed among the galleys and chained to the oar (Anonymous Author 1550, pp. 1488; Kerr 1812, p. 269).

According to the Portuguese chronicler Diogo do Couto, during the closing days of combat, the Portuguese garrison inside Diu's fortress was in a very bad situation, having no more than forty soldiers still active in the defence of the fort (Casale 2010, p. 60). However, the fort did not fall before the Ottoman forces decided to lift the siege and retreat.

\section{The End of the Siege of Diu}

The siege lasted for almost a whole month longer before the retreat. The anonymous Venetian author describes the lifting of the siege in these words: on the 2nd November, the Janissaries and all the rest of the Ottoman army embarked leaving all their artillery behind which they had not the time to carry with them, because they received news that the Portuguese fleet was advancing in order of battle. On the 5th November, twenty Portuguese vessels appeared in sight, and came to anchor twenty miles distance from the Ottoman fleet. On the 6th November, the Pasha gave orders for each of his galleys to fire three guns. This was done at one o'clock at night, and at four o'clock the whole Ottoman fleet departed. So the Venetian sailor claims that the siege lasted two months and two days, from 4th September to 6th November (Anonymous Author 1550, p. 1498; Kerr 1812, p. 273).

Huszthius recounts the lifting of the siege in these words: after two months of fighting (he is almost always vague in his numbers), Portuguese fleet appeared. Hâdım Süleyman Pasha's informers brought him news of the power of the Portuguese fleet, and their power was apparently greater than the Ottoman fleet's power. Both fleets were firing at each other from distance, and there was smoke everywhere, and fear grew amongst the crew. Huszthius and soldiers around him were anticipating a bloody and unpredictable battle. He states that Hâdım Süleyman Pasha knew that the wind was favourable for the Portuguese fleet. That is why he ordered his men to load the cannons and fresh water as if they were to confront the enemy. But during the night the trumpet was sounded and the fleet turned around and headed towards Aden 
(Huszthius 1881, p. 17; Matković 1881, p. 136). It is interesting how Huszthius clearly mentions the trumpet which was his instrument on Yusuf Hamid's ship.

The siege of Diu alone lasted 40 days according to Huszthius and the Venetian author, but only 20 days according to Hammer-Purgstall whose sources declare that the siege of Diu failed because of food shortage on the Ottoman ships and not because of the threat coming from the anticipated arrival of the Portuguese fleet (Hammer 1828, Vol. III, pp. 210-211). Huszthius's travelogue confirms that explanation because he mentions that the water and food rations on the ships were spent, and bread was full of worms. Also, the meat was not dried properly, and the water had a smell. They were eating onions with bad salt and cheese, claims Huszthius, and olive oil was scarce (Huszthius 1881, p. 18; Rački 1858, pp. 501-502).

The conclusion that Hâdım Süleyman Pasha decided to lift the siege and retreat because of poor logistics of the fleet seems very plausible, because the new Gujarati Sultan, Mahmud Shah III, refused to give the Ottomans food and water and visit Hâdım Süleyman's main ship. Maybe he was afraid that the Pasha would hang him, as he did with the Emir of Aden (Hammer 1828, Vol. III, pp. 210-211). So Hâdım Süleyman Pasha probably did not want to wait until the shortage of food and water became a substantial problem for his fleet.

Basing his information on the Portuguese sources about the siege of Diu, Ertuğrul Önalp also concludes that Hâdım Süleyman Pasha's military expedition was unsuccessful due to the decision of the Gujarati ruler and other local Muslim rulers not to provide the needed food and ammunition for the Ottoman soldiers. Furthermore, Önalp asserts that Hâdım Süleyman Pasha's failure resulted from his bad administration and the extraordinary impetuousness of the Portuguese soldiers in defending the fortress (Önalp 2008, pp. 196, 216). Both the assertion that Hâdım Süleyman Pasha decided to lift the siege because of a hoax by Khoja Zaffar and the whole narration of the end of the siege (Önalp 2008, pp. 223-226) are a bit "cinematic", because they rely too much on the portrayal by the Portuguese authors who cannot be taken as completely credible. One should probably be more reliant on the first-hand testimonies of Huszthius and the anonymous Venetian author because of their impartiality.

\section{The Voyage from Diu back to Suez}

The two narrators have many other similar or even completely exact commentaries of the events that happened during the Ottoman naval campaign. For example, Huszthius claims that it took the Ottoman fleet only 19 days to come from Aden to Diu, but 34 days from Diu to Aden, because the sea was stormy and windy on their way to Diu, while it was calm throughout their way back (Huszthius 1881, p. 17; Matković 1881, p. 137). The Venetian sailor also states that the fleet departed from Diu with hardly any wind and that the weather was calm for days on their way back towards Aden. He added later in his journal that for a couple of days the fleet made no progress on the open seas, on account of the weather being dead calm (Anonymous Author 1550, pp. 1498, 1500-1501; Kerr 1812, pp. 273, 274). 
One other commentary that can be found in both testimonies is a description of the way Ottoman soldiers loved to brag about their exploits during the Indian campaign. At every place where the Ottoman fleet stopped on their return voyage, claims the anonymous Venetian, the Ottoman soldiers told that they had conquered the whole country of India, and had cut all the Christians in India to pieces (Anonymous Author 1550, pp. 1500-1501; Kerr 1812, pp. 273-274). Huszthius also describes Ottoman boastfulness in his recount of the Indian campaign (Huszthius 1881, p. 18; Matković 1881, pp. 136-137).

As for the information on the duration of the campaign, the Venetian sailor wrote in his testimony that the Ottoman fleet left Suez on 27th June 1538 and came back on 16th June 1539. On the other hand, Huszthius wrote that they left Suez on 24th June 1538 and that they came back on 24th June 1539. The former author's dates should be deemed as more precise. Both authors mention that the fleet had not set out from Suez or even arrived to Suez as a whole, but as a band of ships that entered the city successively in a range of days, and this may be the reason for the discrepancy (Huszthius 1881, p. 17; Matković 1881, pp. 137, 140; Anonymous Author 1550, pp. 1477, 1507; Kerr 1812, pp. 259, 279). Portuguese authors note the same date as the date of departure. As for Turkish historians, Mustafa Cezar notes 13th June as the date of departure, and Ertuğrul Önalp concurs (Cezar 1958, p. 999; Önalp 2008, p. 202).

There are some other discrepancies too in the chronology of the two authors. Huszthius had not written a journal like the Venetian author, so his dates seem to be more disputable. For instance, according to Huszthius, on their way to India the Ottoman fleet arrived at Aden in October 1538, whereas according to the Venetian, on the $3 \mathrm{rd}$ August 1538, and this latter date is more probable because the voyage from Suez to Aden could not have lasted three months. Also, according to Huszthius, it took them 19 days to come from Aden to Diu; according to the Venetian, it took them 16 days (19th August-4th September 1538) for the same voyage. The siege lasted 40 days (Huszthius) or approximately 40 days (the Venetian author), but Huszthius says in one place that after two months came the Portuguese fleet; the Venetian says that the Ottoman fleet came to Diu on 4th September, and the Portuguese fleet on 5th November. The voyage back to Aden lasted 34 days (Huszthius) or 30 days (the Venetian author: 6th November-5th December) (Matković 1881, p. 146). We believe that the anonymous Venetian sailor offers more precise dates than Huszthius, but even his testimony should be compared with all other sources because of his tendency to quote other people's stories, as we have mentioned before.

There are some events that only Huszthius describes in his account of the Ottoman campaign. For instance, because of the sporadic dead calm on the sea, the sails were of no use, so the chained Venetian rowers had to row more than usual, and Huszthius obviously saw them and showed empathy in his travelogue: he wrote about the whips that were used to force them to row harder (Huszthius 1881, p. 18; Matković 1881, p. 146). Another event that Huszthius deemed important enough to share in his travelogue is that the ship of the Arab captain, on which Huszthius served as trumpeter, sailed in front of all other ships and guided them on their way back from Diu to Aden. During the night, on the bow of the mentioned ship a lamp was lit, and it served 
as a signpost for all the other ships as it guided them through the dark of the vast spaces of the Indian Ocean (Huszthius 1881, p. 18; Matković 1881, p. 146).

Both authors describe on many occasions Hâdım Süleyman Pasha's cruelty. For example, Huszthius states that not far from the city of Zabid (today in Northwestern Yemen), the Pasha took eighty Portuguese prisoners to the shore and had them executed (Huszthius 1881, p. 17; Matković 1881, p. 136). On the other hand, the Venetian sailor states that on the 10th March, close to the city of Zabid, the Pasha ordered all the 146 Portuguese prisoners (Ertuğrul Önalp cites all other sources and notes only 140 prisoners) to be brought bound to the shore, and then their heads were cut off. The head of the chief (probably captain Pacheco, the commander of the captured tower called Gogola) was flayed and his skin was salted and filled with straw. The noses and ears of all the rest were cut off and put into bags to be sent to the sultan (Anonymous Author 1550, p. 1502; Kerr 1812, p. 275).

\section{Conclusion}

What were the consequences of the Ottoman naval campaign in India? First of all, the conquest of Yemen created the basis for the Ottoman province of Yemen, and made it easier for the Ottomans to defend the Red Sea and conquer the Horn of Africa, and further (Black 2002, p. 60). Also, after the expedition, Hâdım Süleyman Pasha was rewarded for the conquest of Yemen and promoted to the rank of Grand Vizier of the Ottoman Empire (Hammer 1828, p. 211).

But the failure of the naval campaign to capture Diu and other Portuguese colonies in western India was a crucial point in the history of Ottoman expansive endeavours in the Indian Ocean and, especially, India. Hâdım Süleyman Pasha's unsuccessful campaign on the shore of Gujarat in India is the farthest point that the Ottoman Empire's forces ever reached in the East, and Huszthius's travelogue represents a valuable first-hand account of the Indian campaign. His testimony can be deemed a neutral account, because he was neither a Portuguese nor a Turk, and the military exploits of either of those countries were not important to him. In that fact lies the importance of Huszthius's work: it can give us a more balanced view of the aforementioned events, also adding some previously unknown information. The best way to prove this assertion was to compare his recount with other mentioned accounts of the Ottoman naval campaign (1538-1539).

\section{Bibliography}

\section{Primary Sources}

Anonymous Author (1550): Viaggio scritto per un comito veneziano, che fu condotto prigione dalla città de Alessandria fino al Diu nella India, col suo ritorno poi al Cairo del 1538. In: Giovan Battista Ramusio: Delle navigationi et viaggi. Vol. II. Venezia, Tommaso Giunti, pp. 14761509. 
Çelebi, Kâtib (2007): Deniz Savaşları Hakkında Büyüklere Armağan. Tuhfetü'l-Kibār fi Esfari'lBihar. Istanbul, Kabalc1 Yayınevi.

Diogo do Couto (1777): Da Ásia. Lisbon, Régia Officina Typografica.

Huszthius, Georgius (1881): Descriptio peregrinationis Georgii Huszthii. In: Matković, Petar (ed.): Descriptio peregrinationis Georgii Huszthii (Codex bibiothecae vaticanae Romae, Reg. num. 931). Starine (Zagreb) Vol. 13, pp. 1-38.

Lopes de Sousa Coutinho (1890): História de cerco de Dio. Lisbon.

\section{Secondary Sources}

Aslan, Adnan (1999): Süleyman Pasha (Hadım). In: Işın, Ekrem-Kara, İsmail (eds): Yaşamları ve Yapitlartyla Osmanlılar Ansiklopedisi. Vol. 2. Istanbul, Yapı Kredi Kültür Sanat Yayıncılık A.Ş., p. 567.

Black, Jeremy (2002): European Warfare, 1494-1660. Palgrave, Routledge.

Casale, Giancarlo (2010): The Ottoman Age of Exploration. New York, Oxford University Press.

Cezar, Mustafa (1958): Resimli-haritall mufassal Osmanlı tarihi. Vol. II. Istanbul, Şehir Matbaası.

Hammer, Joseph von (1828): Geschichte des osmanischen Reiches. Vol. III. Pest, C. A. Hartleben.

Homann, H. D. (1995): Schiltberger, Johannes. In: Auty, Robert (ed.): Lexikon des Mittelalters. Vol. VII. München, LexMA-Verlag, pp. 1465-1466.

Horányi, Elek (1776): Memoria Hungarorum et provincialium scriptis editis notorum. Vol. I. Vienna, Löwe.

Humski, Vera (2002): Hus, Juraj. In: Kovačec, August (editor-in-chief): Hrvatska enciklopedija. Vol. 5. Zagreb, Leksikografski zavod Miroslav Krleža, p. 17.

Istvánffy, Miklós (1622): Nicolai Isthvanfi Pannoni Historiarvm de rebvs Vngaricis Libri XXXIV. Vol. XI. Köln, Antonius Hieratus.

Kerr, Robert (1812): A General History and Collection of Voyages and Travels. Vol. VI. Edinburgh, George Ramsay and Company.

Krasić, Stjepan (1993): Đurđević, Bartul. In: Macan, Trpimir (editor-in-chief): Hrvatski biografski leksikon. Vol. 3. Zagreb, Leksikografski zavod Miroslav Krleža, p. 68.

Kurtoğlu, Fevzi (1940): Hadım Süleyman Paşa'nın Mektupları ve Belgrad'ın muhasara planı. Belleten 9, pp. 63-73.

Laszowski, Emilij (1925): Znameniti i zaslužni Hrvati 925-1925. Zagreb, Hrvatski štamparski zavod.

Mathew, K. M. (1988): History of the Portuguese Navigation in India. New Delhi, Mittal Publications.

Matković, Petar (1881): Gjuro Hus, Hrvat iz Rasinje, glasovit putnik XVI. vieka. Rad Jugoslavenske akademije znanosti i umjetnosti. Vol. 55. Lavoslav Hartman, pp. 116-184.

Melzig, Herbert (1943): Büyük Türk Hindistan kapılarında: Kanuni Sultan Süleyman devrinde admiral Hadım Süleyman Paşa'nın Hint seferi. İstanbul, Selâmi Sertoğlu Kitabevi.

Miličić, Irena (2013): Književnost ili povijest? Knjižica o opisu putova u Tursku: Feliks Petančić i njegov renesansni bestseller. Povijesni prilozi (Zagreb) Vol. 44, No. 1, pp. 155-168.

Mughul, Muhammed Yakub (1974): Kanuni Devri Osmanlıların Hint Okyanusu Politikasl ve Osmanl-Hint Müslümanlarl Münasebetleri, 1517-1538. İstanbul, Fetih Yayınevi.

Önalp, Ertuğrul (2008): Hadım Süleyman Pasha'nın 1538 yılındaki Hindistan Seferi. OTAM (= Ankara Üniversitesi Osmanlı Tarihi Araştırma ve Uygulama Merkezi Dergisi) No. 23, pp. $195-239$.

Rački, Franjo (1858): Crtice iz putopisa Jurja Hustoga. Neven. Zabavan, poučan i znanstven list Vol. 7, No. 31, pp. 485-489; No. 32, pp. 501-504. 
Rákóczi, István (1993): Marginais europeus no Estado da Índia: Pontos de vista, experiencias e estatutos vários. In: Encontro sobre Portugal e a Índia. Lisboa, Fundação das Casas de Alorna e Fronteira, pp. 1-8.

Rákóczi, István (1998): Adem turca e Diu Portuguesa num documento de 1538. In: de Matos, Artur Teodoro-Reis Thomaz, Luís Filipe (eds): A carreira da Índia e as rotas dos Estreitos: Actas do VIII. Seminário Internacional de História Indo-Portuguesa. Angra do Heroísmo, Seminário Episcopal de Angra, pp. 519-526.

Rákóczi, István (2011): De D. Luís e dos Turcos: A problemática do Turco numa visao-estratégica global na primeira metade do século XVI. In: Contente Domingues, Francisco (ed.): X Simpósio de História Marítima. Os Mares do Oriente - A presença portuguesa circa 1507. Lisboa, Academia da Marinha, pp. 1-10.

Ribeiro, Luciano (1958): O primeiro cerco de Dio. Studia No. 1, pp. 201-295.

Ribeiro, Luciano (1962): Preâmbulos do primeiro cerco de Diu. Studia No. 10, pp. 151-193.

Ribeiro, Luciano (1964): Em torno do primeiro cerco de Diu. Studia No. 13-14, pp. 41-104.

Ribeiro, Luciano (1966): Mais documentos relativos ao primeiro cerco de Dio. Lisbon, Centro de Estudos Históricos Ultramarinos.

Stepanić, Gorana (2011): Creating a Value-added Text: Descriptio Peregrinationis Georgii Huszthii. Systasis. E-journal of the Association of Classical Philologists Antika Vol. 18, pp. 114. http://www.systasis.org/index.php/en/

Tardy, Lajos (1977): Rabok, követek, kalmárok az oszmán birodalomról [Prisoners, ambassadors and merchants on the Ottoman Empire]. Budapest, Gondolat.

Yavuz, Hulusi (1984): Kâbe ve Haremeyn İçin Yemen'de. Osmanlı Hakimiyeti 1517-1571. İstanbul, Tanin Matbaası. 